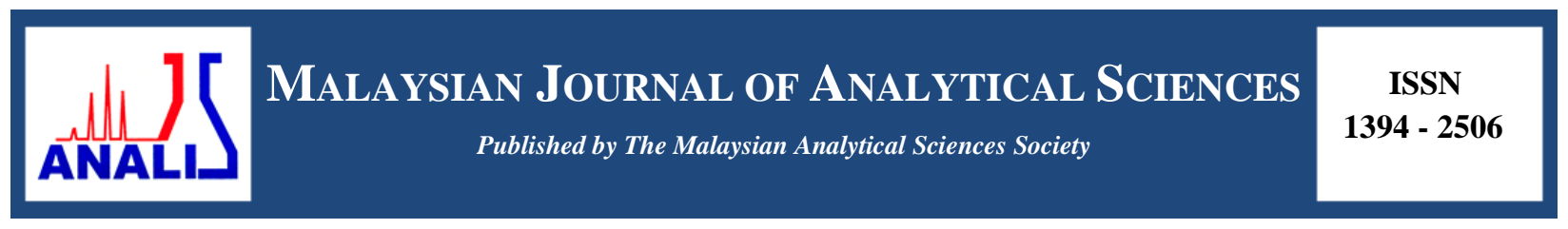

\title{
IDENTIFICATION OF VOLATILE SECONDARY METABOLITES FROM AN ENDOPHYTIC MICROFUNGUS Aspergillus nomius KUB105
}

\author{
(Pengenalpastian Metabolit Sekunder Meruap daripada Kulat Mikro Endofitik \\ Aspergillus nomius KUB105) \\ Lateef Adebola Azeez $^{1,2} *$, Sepiah Muid ${ }^{1}$, Bolhassan Mohamad Hasnul ${ }^{1}$ \\ ${ }^{l}$ Department of Plant Science and Environmental Ecology, Faculty of Resource Science and Technology, \\ Universiti Malaysia Sarawak, 94300 Kota Samarahan, Sarawak, Malaysia \\ ${ }^{2}$ Department of Plant Biology, Faculty of Life Science, \\ University of Ilorin, Nigeria \\ *Corresponding author: lateef.aa@unilorin.edu.ng
}

Received: 12 August 2015; Accepted: 9 May 2016

\begin{abstract}
Microfungi are a highly diverse group of micro-organisms and important components of the ecosystem with great potential for diverse metabolite production. During a survey of microfungi on leaves in a National Park in Sarawak, an uncommon endophytic microfungus Aspergillus nomius was encountered. The metabolite production of this microfungus was investigated by growing it in a liquid basal medium for 2 weeks. Gas Chromatography - Mass Spectrometry (GC-MS) and Fourier Transform Infrared (FTIR) profiling of the secondary metabolites produced by this microfungus in the liquid medium revealed the presence of 46 different secondary metabolites. The metabolites include saturated hydrocarbons, alkyl halides, alcohols and an unsaturated hydrocarbon. Majority of the metabolites produced were saturated hydrocarbons. Tetracosane, Icosane and 10-Methylicosane were the most abundant metabolites identified while heptadecane and 2,4-dimethylundecane were the least abundant respectively. This study is the first GC-MS and FTIR report of secondary metabolites from A. nomius. The results from this study confirm the ability of microfungi to produce diverse metabolites, including saturated hydrocarbons.
\end{abstract}

Keywords: Aspergillus nomius, endophytic fungi, gas chromatography, hydrocarbons, secondary metabolites

\begin{abstract}
Abstrak
Kulat mikro adalah kumpulan yang pelbagai daripada organisma kecil dan merupakan komponen penting dalam ekosistem dengan potensi besar dalam penghasilan pelbagai metabolit. Kulat mikro endofitik yang jarang dijumpai, iaitu Aspergillus nomius telah ditemui semasa kaji selidik kulat mikro atas daun yang dijalankan di Taman Negara, Sarawak. Penghasilan metabolit oleh kulat mikro ini telah dikaji dengan menumbuhkankannya dalam medium cecair asas selama dua minggu. Penghasilan sebanyak 46 metabolit sekunder oleh kulat mikro ini telah disahkan melalui penggunaan Kromatografi Gas Spektrometri Jisim (GC-MS) dan profil (FTIR). Metabolit yang terhasil termasuklah hidrokarbon tepu, alkil halida, alkohol dan hidrokarbon tidak tepu. Kebanyakan metabolit yang dihasilkan adalah hidrokarbon tepu. Tetrakosana, Ikosana dan 10 Metilikosana adalah metabolit yang paling banyak dikenal pasti manakala heptadekana dan 2,4-dimetilundekana adalah yang paling sedikit. Kajian ini merupakan kajian pertama penghasilan metabolit sekunder dari A. nomius melalui penggunaan GC-MS dan FTIR. Hasil kajian ini mengesahkan kebolehan kulat mikro untuk menghasilkan pelbagai metabolit termasuklah hidrokarbon tepu.
\end{abstract}

Kata kunci: Aspergillus nomius, kulat endofitik, kromatografi gas, hidrokarbon, metabolit sekunder 


\section{Azeez et al: IDENTIFICATION OF VOLATILE SECONDARY METABOLITES FROM AN ENDOPHYTIC MICROFUNGUS Aspergillus nomius KUB105}

\section{Introduction}

Fungal secondary metabolites are important natural products from fungi. There are many undiscovered volatile organic compounds produced by fungi. The high diversity of fungi with many species yet to be discovered, coupled with the relatively insufficient research on fungal metabolites puts fungi as a promising source of useful compounds for biotechnological, pharmacological, medicinal, agricultural and industrial applications. There are over 5.1 million fungal species in the world as estimated by Blackwell [1] and only few have been studied for their secondary metabolites production $[2,3]$.

Fungal secondary metabolites are organic compounds that are not involved in the normal growth and development of the fungi [4]. Unlike the primary metabolites, secondary metabolites does not play a key role in the survival of an organism and are frequently produced in high amounts during an organism's transition from active phase of growth to stationary phase [5]. These metabolites are involved in different biological processes in their host such as defence against predators; diseases; parasites; bio-control of pathogens and for communication between micro-organisms and their environment $[6,7]$. Fungal metabolites have been useful as anti-cancer drugs, anti-oxidants, anti-viral, immunosuppressive and immunomodulatory compounds [8-11].

Recently, Strobel et al. [12] discovered the production of biodiesel by the microfungus Gliocladium roseum. They discovered that G. roseum produced an array of chemical compounds which include saturated hydrocarbons such as undecane, alcohols such as 2-Octanol and other compounds classified as esters and acids. In addition, about 270 secondary metabolites were identified from the liquid culture of Trichoderma harzianum with some compounds identified for the first time from T. harzianum [13]. Considering the high diversity of fungi [1], many species are yet to be studied for their secondary metabolites as compared to the few published reports $[3,2]$.

This study was aimed to identify the volatile secondary metabolites produced in liquid culture of an endophytic microfungus, Aspergillus nomius KUB105, isolated during a microfungal survey using Gas Chromatography-Mass Spectrometry (GC-MS) and Fourier Transform Infrared (FTIR).

\section{Isolation and identification of the Microfungus}

\section{Materials and Methods}

A. nomius KUB105 fungus was isolated during a survey of microfungi on leaves of Belian tree (Eusideroxylon zwageri) collected from Kubah National Park, Sarawak, Malaysia. The leaf samples collected were processed for endophytic microfungal isolation [14], plated on $3 \%$ Malt Extract Agar (MEA) and incubated at room temperature. A. nomius was then isolated and identified from segments of the leaf samples after seven days. This microfungus was identified based on its microscopic and cultural morphological characteristics in addition to molecular identification to confirm the identity of the microfungus.

\section{Molecular identification of $A$. nomius KUB105: Total genomic DNA extraction}

Isolates of A. nomius KUB105 was grown on Potato Dextrose Agar (PDA) and incubated at room temperature (27 \pm $2{ }^{\circ} \mathrm{C}$ ) for three days before harvesting for DNA extraction. Mycelia of the isolates (about $500-700 \mathrm{mg}$ ) were scraped from the surface of the culture media using sterilized razor blades into a $2 \mathrm{~mL}$ eppendorf tube. The total genomic DNA was extracted using the CTAB method [15].

The extracted DNA was verified for successful extraction by gel electrophoresis and if successful, the sample is used immediately for Polymerase Chain Reaction (PCR) or stored at $4{ }^{\circ} \mathrm{C}$ for further use. The internal transcribed spacer (ITS) gene regions of the total genomic DNA were amplified by PCR using the primer pairs ITS 5 (5'GGAAGTAAAAGTCGTAACAAGG-3') and ITS 4 (5'-TCCTCCGCTTATTGATATGC-3') [16] in a SensQuest lab cycler. A PCR mixture of $25 \mu \mathrm{L}$ total volume was used. The master mix contains $5 \mu \mathrm{L}$ of $5 \times \mathrm{Mg}$ free-PCR buffer, $2 \mu \mathrm{L}$ of $\mathrm{MgCl}_{2}, 0.5 \mu \mathrm{L}$ of dNTPs, $1.5 \mu \mathrm{L}$ of each primers, $0.15 \mu \mathrm{L}$ of Fementas Taq DNA polymerase and $12.85 \mu \mathrm{L}$ of double-sterilised distilled water $\left(\mathrm{ddH}_{2} \mathrm{O}\right)$ and $1.5 \mu \mathrm{L}$ of DNA template including a tube for control reaction with $\mathrm{ddH}_{2} \mathrm{O}$ as template instead of DNA. The PCR programme was set at initial denaturation of 2 min at 94 ${ }^{\circ} \mathrm{C}$, followed by 35 cycles of $94{ }^{\circ} \mathrm{C}$ for $1 \mathrm{~min}, 55^{\circ} \mathrm{C}$ for $1 \mathrm{~min}, 72{ }^{\circ} \mathrm{C}$ for $1 \mathrm{~min}$ and final extension of $72{ }^{\circ} \mathrm{C}$ for 10 min. The PCR products were gel electrophoresed as described for genomic DNA detection above using $2 \mu \mathrm{L}$ of 
PCR products and $2 \mu \mathrm{L}$ of DNA marker. Successful PCR products were sent to a private sequencing company $\left(1^{\text {st }}\right.$ Base, Asia) for both forward and reverse primer sanger sequencing.

The sequences obtained from the sequencing company were confirmed to belong to the proposed microfungi using BLAST-n on the GenBank website [17]. SeqTrace version 0.9.0 software [18] was used to obtain a consensus sequence from the forward and reverse sequences. The sequence obtained was submitted to the GenBank to obtain an accession number. Similar reference sequences were downloaded from GenBank for phylogenetic analysis following a similarity search. Sequences were aligned using T-coffee alignment software [19] and manually adjusted using AliView Version 1.17-beta1 [20] where necessary. Phylogenetic analysis was done using MEGA 5.0 [21].

\section{Cultivation of $A$. nomius KUB 105 for metabolite production}

A. nomius KUB105 was initially grown on solidified $3 \%$ MEA at $27 \pm 2{ }^{\circ} \mathrm{C}$ for 3 days to produce mycelial inoculum for the liquid culture. A liquid basal medium was used for the growth of this microfungus for secondary metabolites extraction using the method proposed by McMullin et al. [22]. The basal medium contained, per litre: 10.00 g glucose, 2.00 g peptone, $0.30 \mathrm{~g} \mathrm{KH}_{2} \mathrm{PO}_{4}, 0.30 \mathrm{~g} \mathrm{MgSO}_{4}, 0.20 \mathrm{~g} \mathrm{CaCl}_{2}, 0.20 \mathrm{mg} \mathrm{FeSO}$, $0.10 \mathrm{mg} \mathrm{CuSO}$, 0.5 mg pyridoxine, $0.5 \mathrm{mg}$ niacin and $0.3 \mathrm{mg} \mathrm{ZnSO}$. All chemicals were of analytical grade. An amount of $30 \mathrm{~mL}$ of the basal medium was poured in $100 \mathrm{~mL}$ conical flask and autoclaved for $15 \mathrm{~min}$ at $121{ }^{\circ} \mathrm{C}$. After cooling, agar plugs of A. nomius were aseptically cut with a $5 \mathrm{~mm}$ cork borer into the autoclaved basal medium, sealed with aluminium foil and incubated in a stationary condition for 2 weeks at $27 \pm 2{ }^{\circ} \mathrm{C}$ with alternating 12 hours darkness and light. Three replicates were prepared.

\section{Extraction and identification of secondary metabolites}

After 2 weeks of growth, the liquid culture was filtered using Whatmanns No. 1 filter paper $(90 \mathrm{~mm}$ diameter) to separate the mycelium from the filtrate. The cell free crude filtrate was then extracted by liquid-liquid extraction method. $30 \mathrm{~mL}$ of ethyl acetate was added to the culture filtrate, mixed together and the extraction process was left overnight to ensure maximum extraction. $15 \mathrm{~mL}$ of hexane was then added to the ethyl acetate extract. This is to allow the metabolites to be extracted into hexane, since the hexane extract will be injected into the GC-MS. The solvents were then cleaned up using a silica-gel column chromatography. The remaining solvent (hexane) was then carefully evaporated at $40{ }^{\circ} \mathrm{C}$ until only $2 \mathrm{~mL}$ of the solvent remained. $2 \mathrm{~mL}$ of the hexane extract was then used for Gas Chromatography-Mass Spectrometry (GC-MS) analysis. The basal medium hexane extract without the microfungus was also processed to serve as a control.

The secondary metabolites from the hexane extract were identified by a GC-MS (Shimadzu, Japan) equipped with a (QP2010 plus) mass selective detector. The ionization energy used was $70 \mathrm{eV}$. Preliminary identification was done with a non-polar capillary column (BP5) $30 \mathrm{~m} \times 0.25 \mathrm{~mm} \times 0.25 \mathrm{~mm}$. The oven program had an initial temperature of $50{ }^{\circ} \mathrm{C}$ for $5 \mathrm{~min}$, then a $10^{\circ} \mathrm{C} / \mathrm{min}$ run to $260^{\circ} \mathrm{C}$ with a final hold at $260{ }^{\circ} \mathrm{C}$ for $10 \mathrm{~min}$. The injector temperature was kept at $280{ }^{\circ} \mathrm{C}$ (splitless) and detector temperature was at $280{ }^{\circ} \mathrm{C}$. The carrier gas was purified Helium (99.99 $\%)$ at a linear flow rate of $1 \mathrm{~mL} / \mathrm{min}$. The MS detector was operated at $280{ }^{\circ} \mathrm{C}$ and the scan range was from 40 to $500 \mathrm{~m} / \mathrm{z}$.

All detected compounds were putatively identified by mass spectral database search of the National Institute of Standards and Technology (NIST) followed by matching of the mass spectral data. Fourier Transform Infrared Spectroscopy (FTIR) analysis was also done to show the different functional groups present in our sample using a Thermo scientific Nicolet iS50 FTIR machine. Spectral shifts obtained were interpreted with reference to shifts in the peaks of the various functional groups.

\section{Identification of the microfungus}

\section{Results and Discussion}

The cultural characteristics of the isolates used in this study were similar to those of microfungi in the Aspergillus flavus section which includes A. flavus, A. parasiticus and A. nomius. The colony observe colour was green (which indicates the matured spores) with white colour at the margins (the young spores), the reverse side was creamish to light cream-brown (Figure 1). The mycelia reached about $8 \mathrm{~cm}$ diameter in seven days and is aerial. The mycelium 


\section{Azeez et al: IDENTIFICATION OF VOLATILE SECONDARY METABOLITES FROM AN ENDOPHYTIC MICROFUNGUS Aspergillus nomius KUB105}

is septate with a globus terminal head conidiophore having spores arranged radially in chains and the spore surface is rough. However, in this study, A. nomius is different from other members of the A. flavus section by having a uniseriate conidial head and a rough conidia (as seen by Scanning electron microscopy, result not shown in this paper) and by its molecular identification (Figure 2) with accession number KR737578.

A. nomius also have an indeterminate sclerotia and a lower optimum temperature for growth as compared to the other species in the A. flavus section [23].
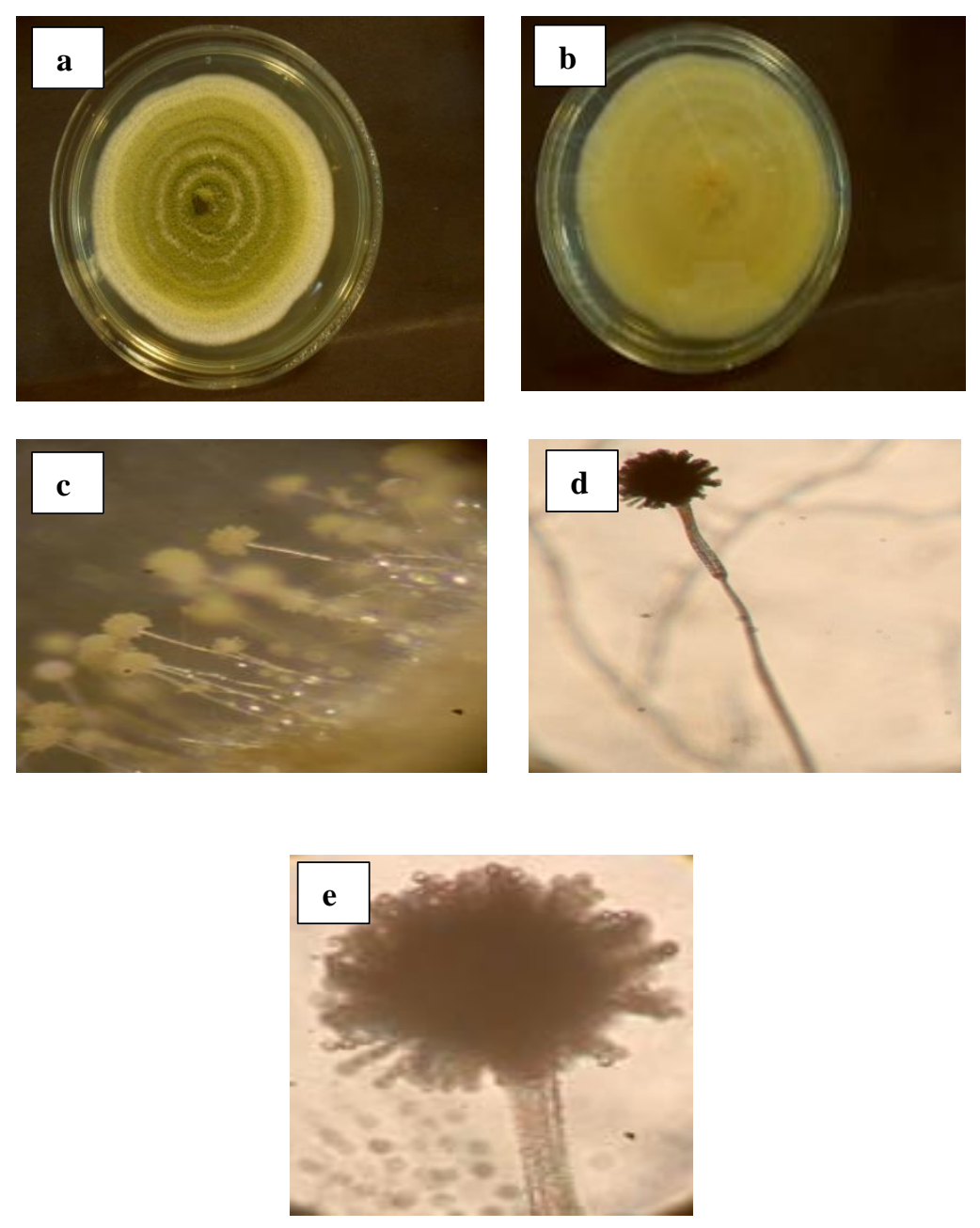

Figure 1. Aspergillus nomius: (a) cultural morphology, observe surface; (b) reverse surface; (c) conidiophores with conidial head on PDA; (d-e) conidial heads 


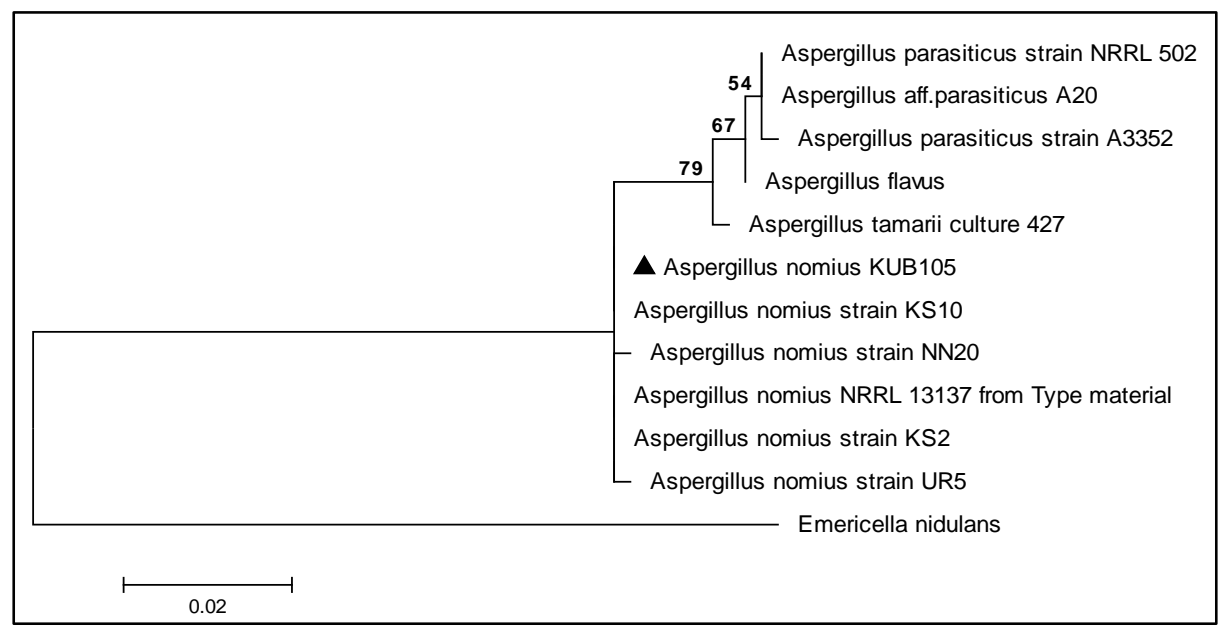

Figure 2. Molecular phylogenetic analysis by Maximum Likelihood method for identification of A. nomius KUB105 (KR737578) performed using MEGA5.1

\section{Identification of metabolites from culture filtrate of $A$. nomius KUB105}

After subtraction of the compounds in the control, GC-MS chromatograms of hexane extract of A. nomius (Figure 3) revealed 46 metabolites identified with reference to NIST mass spectral database which corresponds to each compound's identity. The identified metabolites include 43 saturated hydrocarbons, one alcohol, one ester \& one chloro-hydrocarbon (alkyl halide) compounds. Tetracosane was the most abundant compound produced by $A$. nomius KUB105 with the highest peak area, while normal heptadecane and 2,4-Dimethylundecane were the least abundant (Table 1).

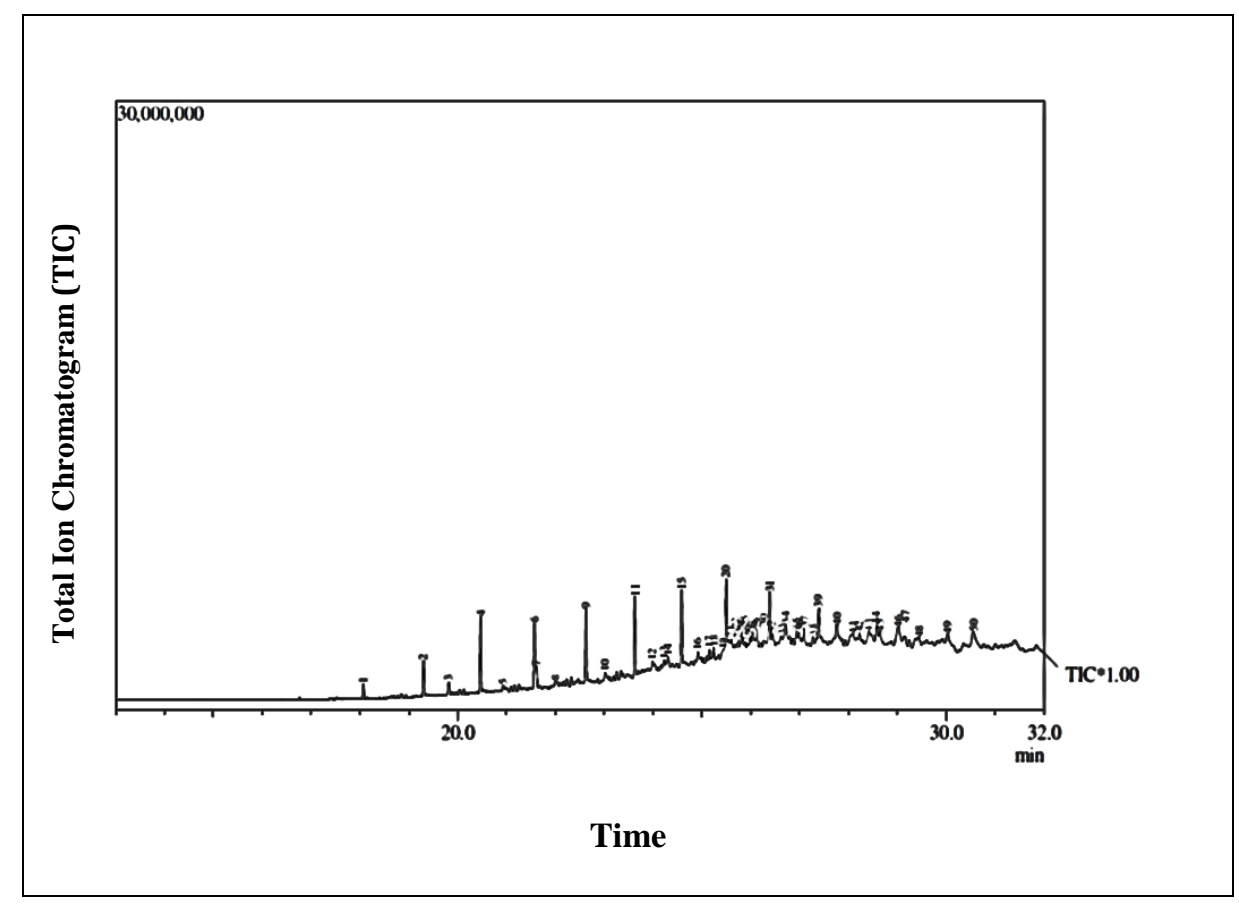

Figure 3. GC-MS chromatogram of secondary metabolites from culture of A. nomius KUB105 
Azeez et al: IDENTIFICATION OF VOLATILE SECONDARY METABOLITES FROM AN ENDOPHYTIC MICROFUNGUS Aspergillus nomius KUB105

Table 1. List of various secondary metabolites identified from culture of A. nomius by GC-MS

\begin{tabular}{|c|c|c|c|c|c|}
\hline Number & Family & Metabolite Name & $\begin{array}{l}\text { Structure/ } \\
\text { Formula }\end{array}$ & $\begin{array}{l}\text { Retention } \\
\text { Time (min) }\end{array}$ & $\begin{array}{c}\text { Abundance } \\
(\%)\end{array}$ \\
\hline 1 & Alkane & n-Pentadecane & $\mathrm{C}_{15} \mathrm{H}_{32}$ & 18.07 & 0.78 \\
\hline 2 & & n-Hexadecane & $\mathrm{C}_{16} \mathrm{H}_{34}$ & 19.30 & 1.95 \\
\hline 3 & & 2,6,10-Trimethylpentadecane & $\mathrm{C}_{18} \mathrm{H}_{38}$ & 19.82 & 1.03 \\
\hline 4 & & 2,6-Dimethylheptadecane & $\mathrm{C}_{19} \mathrm{H}_{40}$ & 20.45 & 4.52 \\
\hline 5 & & n-Nonadecane & $\mathrm{C}_{19} \mathrm{H}_{40}$ & 20.93 & 0.99 \\
\hline 6 & & Octadecan & $\mathrm{C}_{18} \mathrm{H}_{38}$ & 21.57 & 4.13 \\
\hline 7 & & Pristane & $\mathrm{C}_{19} \mathrm{H}_{40}$ & 21.61 & 1.18 \\
\hline 8 & & Henicosane & $\mathrm{C}_{21} \mathrm{H}_{44}$ & 22.62 & 4.13 \\
\hline 9 & & 6-Propyltridecane & $\mathrm{C}_{16} \mathrm{H}_{34}$ & 23.01 & 0.83 \\
\hline 10 & & Icosane & $\mathrm{C}_{20} \mathrm{H}_{42}$ & 23.63 & 4.71 \\
\hline 11 & & Normal-heptadecane & $\mathrm{C}_{17} \mathrm{H}_{36}$ & 23.99 & 0.68 \\
\hline 12 & & 2-Methylicosane & $\mathrm{C}_{21} \mathrm{H}_{44}$ & 24.23 & 0.75 \\
\hline 13 & & 3-Methylicosane & $\mathrm{C}_{21} \mathrm{H}_{44}$ & 24.31 & 1.45 \\
\hline 14 & & 10-Methylicosane & $\mathrm{C}_{21} \mathrm{H}_{44}$ & 24.58 & 4.62 \\
\hline 15 & Alkane & n-Octacosane & $\mathrm{C}_{28} \mathrm{H}_{58}$ & 24.92 & 1.33 \\
\hline 16 & & 2-Methylnonadecane & $\mathrm{C}_{20} \mathrm{H}_{42}$ & 25.15 & 1 \\
\hline 17 & & 3-Methyltetradecane & $\mathrm{C}_{15} \mathrm{H}_{32}$ & 25.24 & 1.32 \\
\hline 18 & & Pentadecylcyclohexane & $\mathrm{C}_{21} \mathrm{H}_{42}$ & 25.43 & 1.2 \\
\hline 19 & & n-Tetracosane & $\mathrm{C}_{24} \mathrm{H}_{50}$ & 25.49 & 5.76 \\
\hline 20 & Ester & n-Heptadecyl acetate & $\mathrm{C}_{19} \mathrm{H}_{38} \mathrm{O}_{2}$ & 25.61 & 3.8 \\
\hline 21 & Alkene & Neodene & $\mathrm{C}_{20} \mathrm{H}_{40}$ & 25.69 & 1.06 \\
\hline 22 & Alkane & $\begin{array}{l}2,6,10,15- \\
\text { Tetramethylheptadecane }\end{array}$ & $\mathrm{C}_{21} \mathrm{H}_{44}$ & 25.74 & 1.69 \\
\hline 23 & & 9-Methylnonadecane & $\mathrm{C}_{20} \mathrm{H}_{42}$ & 25.81 & 2.69 \\
\hline 24 & & 2,5-Dimethyltridecane & $\mathrm{C}_{15} \mathrm{H}_{32}$ & 25.88 & 0.76 \\
\hline 25 & & 2,4-Dimethylundecane & $\mathrm{C}_{13} \mathrm{H}_{28}$ & 25.92 & 0.68 \\
\hline 26 & & 4-Methyltetradecane & $\mathrm{C}_{15} \mathrm{H}_{32}$ & 25.99 & 1.55 \\
\hline 27 & & 7-Hexylicosane & $\mathrm{C}_{26} \mathrm{H}_{54}$ & 26.04 & 1.84 \\
\hline 28 & & 11-Decyltetracosane & $\mathrm{C}_{34} \mathrm{H}_{70}$ & 26.13 & 2.38 \\
\hline 29 & & 1-Cyclopentyldecane & $\mathrm{C}_{15} \mathrm{H}_{30}$ & 26.26 & 1.26 \\
\hline 30 & & $\begin{array}{l}2,6,10,14- \\
\text { Tetramethylhexadecane }\end{array}$ & $\mathrm{C}_{20} \mathrm{H}_{42}$ & 26.44 & 1.17 \\
\hline 31 & & 8-Hexylpentadecane & $\mathrm{C}_{21} \mathrm{H}_{44}$ & 26.71 & 2.73 \\
\hline 32 & & 11-(1-Ethylpropyl) & $\mathrm{C}_{26} \mathrm{H}_{54}$ & 26.93 & 1.3 \\
\hline 33 & & 2-Methyloctadecane & $\mathrm{C}_{19} \mathrm{H}_{40}$ & 26.99 & 1.22 \\
\hline 34 & & 7-Hexyldocosane & $\mathrm{C}_{28} \mathrm{H}_{58}$ & 27.09 & 1.78 \\
\hline 35 & Alcohol & 2-Hexyl-1-decanol & $\mathrm{C}_{16} \mathrm{H}_{34} \mathrm{O}$ & 27.27 & 0.82 \\
\hline 36 & Alkane & n-Heptacosane & $\mathrm{C}_{27} \mathrm{H}_{56}$ & 27.39 & 2.87 \\
\hline 37 & & $\mathrm{n}$-Tetratetracontane & $\mathrm{C}_{44} \mathrm{H}_{90}$ & 27.76 & 2.21 \\
\hline
\end{tabular}


Table 1 (cont'd). List of various secondary metabolites identified from culture of A. nomius by GC-MS

\begin{tabular}{llllcc}
\hline Number & Family & Metabolite Name & $\begin{array}{l}\text { Structure/ } \\
\text { Formula }\end{array}$ & $\begin{array}{c}\text { Retention } \\
\text { Time (min) }\end{array}$ & $\begin{array}{c}\text { Abundance } \\
\text { (\%) }\end{array}$ \\
\hline 38 & & 9-Octyldocosane & $\mathrm{C}_{30} \mathrm{H}_{62}$ & 28.09 & 2.05 \\
39 & & 3-Methylheptadecane & $\mathrm{C}_{18} \mathrm{H}_{38}$ & 28.23 & 1.08 \\
40 & & n-Tetratriacontane & $\mathrm{C}_{34} \mathrm{H}_{70}$ & 28.41 & 2.52 \\
41 & & (1-Propyldecyl)cyclohexane & $\mathrm{C}_{19} \mathrm{H}_{38}$ & 28.64 & 1.14 \\
42 & Alkyl halide & 1-Chloroheptacosane & $\mathrm{C}_{27} \mathrm{H}_{55} \mathrm{Cl}$ & 29.01 & 3.53 \\
43 & Alkane & Untriacontane & $\mathrm{C}_{31} \mathrm{H}_{64}$ & 29.17 & 1.47 \\
44 & Alkyl halide & 1-Chloroicosane & $\mathrm{C}_{20} \mathrm{H}_{41} \mathrm{Cl}$ & 29.44 & 2.23 \\
45 & Alkane & 11-Butyldocosane & $\mathrm{C}_{26} \mathrm{H}_{54}$ & 30.02 & 1.18 \\
46 & & 11,20-Didecyltriacontane & $\mathrm{C}_{50} \mathrm{H}_{102}$ & 30.55 & 2.85 \\
\hline
\end{tabular}

Most of these hydrocarbons have also been reported by [24-26], and [27] from culture extracts of Aspergillus flavus, A. niger; A. ochraceus, A. niger and A. carbonarius respectively. However, these metabolites are reported for the first time from culture extracts of $A$. nomius using GC-MS.

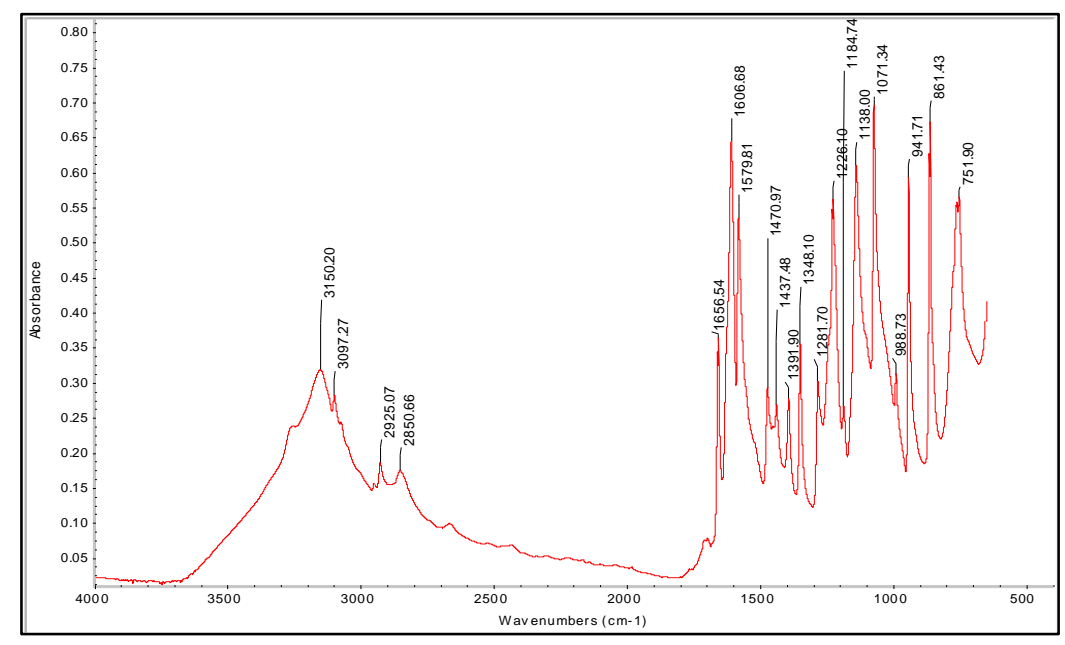

Figure. 4. The FTIR spectrum of the crude extract from liquid culture of A. nomius with bands extending from 550 $-4000 \mathrm{~cm}^{-1}$.

The analysis of the FTIR spectrum indicates the presence of hydrocarbons and alcohol in the extract. The peak obtained at $751.90 \mathrm{~cm}^{-1}$ (Figure. 4) shows the presence of a C-Cl functional group which can be attributed to 1Chloroicosane identified by the GC-MS analysis (see Table 1). The numerous peaks obtained between 861.43 to $1656.54 \mathrm{~cm}^{-1}$ shows the abundance of $\mathrm{C}-\mathrm{H}$ functional groups which can be attributed to the saturated hydrocarbon (alkane) compounds [28] produced by the microfungus. Peaks at 2850.66 to $3150.20 \mathrm{~cm}^{-1}$ indicates the presence of $\mathrm{O}-\mathrm{H}$ functional groups matching with 2-Hexyl-1-decanol and n-Heptadecyl acetate identified by the GC-MS. The spectrum from the FTIR further corroborates the spectral identifications obtained by GC-MS analysis. 


\section{Azeez et al: IDENTIFICATION OF VOLATILE SECONDARY METABOLITES FROM AN ENDOPHYTIC MICROFUNGUS Aspergillus nomius KUB105}

Saturated hydrocarbons are the main ingredients of diesel fuel [12] and the identification of these compounds from culture filtrate of $A$. nomius and other microfungi indicates a close involvement of microfungi in the formation of these compounds through decomposition of certain organic and inorganic matter. Industrial application of the processes involved in the production of these hydrocarbon secondary metabolites coupled with the high diversity and easy growth potentials of microfungi can be a promising option to finding more sources of renewable energy production.

\section{Conclusion}

Our results have shown that saturated hydrocarbons are the major metabolites produced by A. nomius KUB105 grown for 2 weeks on a liquid basal medium (as described) at $27 \pm 2{ }^{\circ} \mathrm{C}$. The findings in this study further support the claim by other researchers about microfungal hydrocarbon-metabolite production. Also, this study has been able to make the first report of the secondary metabolites produced by A. nomius KUB105 identified by GC-MS and FTIR analysis. Further study on the large scale production and purification of these secondary metabolites are necessary to fully utilize these compounds.

\section{Acknowledgement}

The First author thanks Universiti Malaysia Sarawak for the scholarship awarded. The authors are also grateful to Sarawak Forestry Corporation and the Sarawak Government.

\section{References}

1. Blackwell, M. (2011). The fungi: 1, 2, 3 ... 5.1 million species? American Journal of Botany, 98 (3): 426 - 438.

2. Strobel, G. A. and Daisy, B. (2003). Bioprospecting for microbial endophytes and their natural products. Microbiology and Molecular Biology Reviews, 67 (4): 491 - 502.

3. Strobel, G. A. (2014). The use of endophytic fungi for the conversion of agricultural wastes to hydrocarbons. Biofuels, 5(4): 447 - 455.

4. Tamano, K. (2014). Enhancing microbial metabolite and enzyme production: current strategies and challenges. Frontiers in Microbiology, 5: 718 - 723.

5. Agostini-Costa, T. da S., Silveira, D., Bizzo, H. R., Gimenes, M. A., and Vieira, R. F. (2012). Secondary Metabolites. INTECH Open Access Publisher.

6. Netzker, T., Fischer, J., Weber, J., Mattern, D. J., König, C. C., Valiante, V.,Schroeckh, V. and Brakhage, A. A. (2015). Microbial communication leading to the activation of silent fungal secondary metabolite gene clusters. Frontiers in Microbiology, 6: 299 - 302.

7. Vinale, F., Sivasithamparam, K., Ghisalberti, E. L., Marra, R., Barbetti, M. J., Li, H., Woo, S. L. and Lorito, M. (2008). A novel role for Trichoderma secondary metabolites in the interactions with plants. Physiological and Molecular Plant Pathology, 72 (1-3): 80 - 86.

8. Pandi, M., Rajapriya, P. and Manoharan, P. T. (2013). Extraction and characterization of taxol: an anticancer drug from an endophytic and pathogenic fungi. Laboratory Protocols in Fungal Biology, 523 -527.

9. Li, S. Y., Shi, L. J., Ding, Y., Nie, Y. and Tang, X. M. (2015). Identification and functional characterization of a novel fungal immunomodulatory protein from Postia placenta. Food and Chemical Toxicology: An International Journal Published for the British Industrial Biological Research Association, 78: 64 - 70.

10. Marson Ascêncio, P. G., Ascêncio, S. D., Aguiar, A. A., Fiorini, A. and Pimenta, R. S. (2014). Chemical Assessment and Antimicrobial and Antioxidant Activities of Endophytic Fungi Extracts Isolated from Costus spiralis (Jacq.) Roscoe (Costaceae). Evidence-Based Complementary and Alternative Medicine, 2014: 1 - 10.

11. Mizerska-Dudka, M., Jaszek, M., Błachowicz, A., Rejczak, T. P., Matuszewska, A., Osińska-Jaroszuk, M., Stefaniuk, D., Janusz, G., Sulej, J. and Kandefer-Szerszeń, M. (2015). Fungus Cerrena unicolor as an effective source of new antiviral, immunomodulatory, and anticancer compounds. International Journal of Biological Macromolecules, 79: $459-468$.

12. Strobel, G. A., Knighton, B., Kluck, K., Ren, Y., Livinghouse, T., Griffin, M., Spakowicz, D. and Sears, J. (2008). The production of myco-diesel hydrocarbons and their derivatives by the endophytic fungus Gliocladium roseum (NRRL 50072). Microbiology, 154 (11): 3319 - 3328.

13. Siddiquee, S., Cheong, B. E., Taslima, K., Kausar, H., and Hasan, M. M. (2012). Separation and identification of volatile compounds from liquid cultures of Trichoderma harzianum by GC-MS using three different capillary columns. Journal of Chromatographic Science, 50 (4): 358 - 367. 
14. Rakotoniriana, E. F., Munaut, F., Decock, C., Randriamampionona, D., Andriambololoniaina, M., Rakotomalala, T., Rakotonirina, E. J., Rabemanantsoa, C., Cheuk, K. S., Ratsimamanga, U., Mahillon, J., ElJaziri, M., Quetin-Leclercq, J. and Corbisier, A. M. (2008). Endophytic fungi from leaves of Centella asiatica: occurrence and potential interactions within leaves. Antonie van Leeuwenhoek, 93 (1-2): 27 - 36.

15. Murray, M. G., and Thompson, W. F. (1980). Rapid isolation of high molecular weight plant DNA. Nucleic Acids Research, 8 (19): 4321 - 4325.

16. White, T. J., Bruns, T., Lee, S., and Taylor, J. (1990). Amplification and direct sequencing of fungal ribosomal RNA genes for phylogenetics in PCR protocols: A guide to methods and applications. Academic Press, New York, USA., $315-322$.

17. National Center for Biotechnology Information (NCBI). (2015). BLAST: Basic Local Alignment Search Tool. Access online http://blast.ncbi.nlm.nih.gov/Blast.cgi [Retrieved May 7, 2016]

18. Stucky, B. J. (2012). SeqTrace: A graphical tool for rapidly processing DNA sequencing chromatograms. Journal of Biomolecular Techniques, 23 (3): 90 - 93.

19. Di Tommaso, P., Moretti, S., Xenarios, I., Orobitg, M., Montanyola, A., Chang, J.-M.,Taly, J-F, Notredame, C. (2011). T-Coffee: a web server for the multiple sequence alignment of protein and RNA sequences using structural information and homology extension. Nucleic Acids Research, 39 (Web Server issue), W13-17.

20. Larsson, A. (2014). AliView: a fast and lightweight alignment viewer and editor for large datasets. Bioinformatics (Oxford, England), 30 (22): 3276 - 3278.

21. Tamura, K., Peterson, D., Peterson, N., Stecher, G., Nei, M., and Kumar, S. (2011). MEGA5: Molecular evolutionary genetics analysis using maximum likelihood, evolutionary distance, and maximum parsimony methods. Molecular Biology and Evolution, 28 (10): 2731 - 2739.

22. McMullin, D. R., Nsiama, T. K., and Miller, J. D. (2014). Secondary metabolites from Penicillium corylophilum isolated from damp buildings. Mycologia, 106 (4): 621 - 628.

23. Kurtzman, C. P., Horn, B. W., \& Hesseltine, C. W. (1987). Aspergillus nomius, a new aflatoxin-producing species related to Aspergillus flavus and Aspergillus tamarii. Antonie van Leeuwenhoek, 53 (3): 147 - 158.

24. De Lucca, A. J., Boue, S. M., Carter-Wientjes, C. and Bhatnagar, D. (2012). Volatile profiles and aflatoxin production by toxigenic and non-toxigenic isolates of Aspergillus flavus grown on sterile and non-sterile cracked corn. Annals of Agricultural and Environmental Medicine, 19 (1): 91 - 98.

25. Fiedler, K., Schutz, E., and Geh, S. (2001). Detection of microbial volatile organic compounds (MVOCs) produced by moulds on various materials. International Journal of Hygiene and Environmental Health, 204: $111-121$.

26. Siddiquee, S., Azad, S. A., Abu Bakar, F., Naher, L. and Vijay Kumar, S. (2012). Separation and identification of hydrocarbons and other volatile compounds from cultures of Aspergillus niger by GC-MS using two different capillary columns and solvents. Journal of Saudi Chemical Society, 19 (3): 243 - 256.

27. Sinha, M., Sørensen, A., Ahamed, A. and Ahring, B. K. (2015). Production of hydrocarbons by Aspergillus carbonarius ITEM 5010. Fungal Biology, 119 (4): $274-282$.

28. Devi, N. N. and Prabakaran, J. J. (2014). Bioactive metabolites from an endophytic fungus Penicillium sp. isolated from Centella asiatica. Current Research in Environmental \& Applied Mycology, 4 (1): 34 - 43. 